\title{
PHYSICAL-CHEMICAL COMPOSITION AND TECHNOLOGICAL PROPERTIES OF DEMINERALIZED MILK WHEY RECEIVED BY MEMBRANE METHODS
}

\author{
I. O. Romanchuk, A.V. Minorova, N.L. Krushelnytska \\ Institute of Food Resources, NAAS \\ 4a, Yevhena Sverstiuka Str., Kyiv, Ukraine, 02002 \\ E-mail:dairy@ipr.net.ua,MinorovaAnt@gmail.com,enn.makarova@gmail.com \\ Received on July 09, 2018 / Received September 17, 2018 / Accepted November 21, 2018
}

\begin{abstract}
Aim. To investigate the composition and properties of the samples of cheese and acid milk whey, obtained in industrial conditions using a combination of nanofiltration and electrodialysis methods. Methods. Determination of physical-chemical indices using standard methods, study of functional-technological properties of demineralized whey by common methods. Results. It was established that there was high efficiency of applying membrane methods for processing of secondary resources in current conditions of raw materials source, which are presented by different kinds of milk whey, formed during cheese production. It was determined that processing of different kinds of whey using the combination of nanofiltration and electrodialysis methods led to a considerable decrease in the content of ash compared to the initial whey. The level of demineralization of cheese whey may amount to $90 \%$, that of acid whey $-75 \%$. In addition to dry kinds of whey, liquid demineralized whey is of some interest for practical application, which may be used during the production of sour-milk and milk-containing drinks due to a high content of dry substances. It was found that the increase in protein content in dry demineralized whey, obtained using the complex of membrane methods of processing, led to a considerable increase in its foam-forming, moisture-retaining, fat-retaining and emulsifying abilities compared to milk whey, obtained by a traditional technology. Conclusions. It was established that dry demineralized whey, obtained by a combination of nanofiltration and electrodialysis methods, had better organoleptic and physical-chemical indices compared to dry whey. The investigated industrial samples were remarkable for improved functional and technological properties which allows using them in the formulations of other food products.
\end{abstract}

Keywords: nanofiltration, electrodialysis, combined membrane methods, physical-chemical indices, demineralization level, dry demineralized whey, functional-technological properties.

DOI: https://doi.org/10.15407/agrisp5.03.033

\section{INTRODUCTION}

At present the developed countries have accepted a concept of the best available technologies, which means modernization of all the production with the purpose of minimizing a negative effect on environment via maximal processing of raw materials and by-products of production, reducing expenses on reagents and water, ensuring the possibility of water recirculation at enterprises. Membrane processes were proven to be successful in solving these tasks [1].

\footnotetext{
(C) I. O. ROMANCHUK, A. V. MINOROVA, N. L. KRUSHELNYTSKA, 2018
}

The introduction of membrane technologies at milk-processing enterprises allows enhancing the efficiency and cost effectiveness due to the economy of energy resources, more complete use of raw material resources, expanding the assortment, receiving additional profit [2].

Among modern membrane technologies, including reverse osmosis, microfiltration, ultrafiltration, nanofiltration, and electrodialysis, in Ukraine ultrafiltration, nanofiltration and electrodialysis found their practical application.

During nanofiltration (NF) there is concentration of dry substances up to $18-22 \%$ which makes it rea- 


\section{ROMANCHUK et al.}

sonable to use it with the purpose of reducing energy resources compared to whey evaporation in vacuum. Besides, from the practical standpoint the optimal variant of NF-processing is maximal removal of mineral salts and lactic acid from different kinds of milk whey with the most complete retaining of valuable whey components - proteins and lactose, and, as a result, obtaining concentrates, the technological indices of which allow using them in the production of other products [3-6].

Electrodialysis (ED) allows increasing the target indices of demineralization up to $90 \%$, which is especially promising for processing of salty cheese, acid and caseic milk whey [7, 8]. Any kind of whey with the application of demineralization of different level (50, $70,90 \%$ and above) may be standardized by physicalchemical composition and organoleptic indices, it is possible to achieve the category of quality which allows using it in baby food [2].

However, achieving a high level of demineralization is accompanied with a considerable increase in energy expenses, which is economically not substantiated [9]. Taking into consideration the fact that usually not more than $70-80 \%$ of salts are practically removed, electrodialysis is widely used in industrial conditions while desalinizing various kinds of milk whey [10-12].

To increase efficiency, electrodialysis is combined with other membrane methods of separation [2, 13]. In particular, the combination of nanofiltration and electrodialysis is recommended not only to enhance the efficiency of whey processing technology, to economize energy resources, but also to reduce the impact of high temperatures on thermolabile components of milk whey which, at the end, enhances the biological value and improves technological properties of obtained products [14]. Such demineralized dry whey has better taste, physical-chemical characteristics and functionaltechnological properties compared to dry whey, obtained by traditional technology.

Taking the abovementioned into consideration, one may assume that the use of a complex of membrane methods allows increasing the quality of milk whey processing in conditions of a dairy enterprise compared to their separate application. This technology was successfully implemented at some dairy enterprises.

\section{MATERIALS AND METHODS}

Cheese and acid whey, obtained during the production of cheese or lactic cheese and the corresponding kinds of whey after nanofiltration and electrodialysis, were used in the work. Demineralization of milk whey was conducted at experiment electrodialysis (MEGA, Czech Republic) and nanofiltration equipment (GEA, Denmark). Dry samples were obtained by drying the corresponding kinds of whey on spray dryer.

The mass content of moisture in dry products was defined by the standardized method, which is based on the ability of the product to lose free moisture while drying at constant temperature $-(102 \pm 2){ }^{\circ} \mathrm{C}$. The arithmetic mean value of the results of two parallel measurements of one sample was accepted as the final result, the permissible differences between them could not exceed $0.06 \%$.

The mass content of ash was determined by the method, based on ashing 2.8-3.2 g of dry product at the temperature of $(525 \pm 25){ }^{\circ} \mathrm{C}$. The mass content of ash in percentage $(X)$ was calculated according to the formula:

$$
X=\frac{\left(m_{1}-m_{2}\right)}{m} \cdot 100
$$

where $m_{1}-$ mass of a pot with the ashes of the product after ashing, $g ; m_{2}$ - mass of an empty pot after calcination, $g ; m-$ mass of the weighed quantity of product, g; 100 - coefficient of transferring grams into percentage.

The arithmetic mean value of the results of two parallel measurements of one sample was accepted as the final result, the permissible differences between them could not exceed $0.1 \%$.

The mass content of fat was determined by the standardized acid method, based on extracting fat from dry products under the impact of concentrated sulphuric acid and isoamil alcohol with further centrifugation and measuring the volume of fat in the calibrated part of butyrometer. The arithmetic mean value of the results of two parallel measurements of one sample was accepted as the final result, the permissible differences between them could not exceed $0.5 \%$ on condition that the results were within one lowest graduation mark of the butyrometer.

The mass content of lactose was determined by the standardized iodometric method in the weighed quantity of the product of $3.0 \mathrm{~g}$. The arithmetic mean value of the results of two parallel measurements of one sample was accepted as the final result, the permissible differences between them could not exceed $0.2 \%$.

The acidity of dry whey was determined by the standardized titrimetric method using $0.1 \mathrm{~mol} / \mathrm{cu} \mathrm{dm}$. The arithmetic mean value of the results of two parallel 


\section{PHYSICAL-CHEMICAL COMPOSITION AND TECHNOLOGICAL PROPERTIES OF DEMINERALIZED MILK}

measurements of one sample was accepted as the final result, the permissible differences between them could not exceed $0.5 \%$.

The solubility index was determined in one cubic centimeter by the method, based on measuring the volume of insoluble precipitation in the restored sample of dry whey after centrifugation at $8,000 \mathrm{rpm}$ for $5 \mathrm{~min}$. The arithmetic mean of the results of two parallel measurements of one sample was accepted as the final result, the permissible differences between them could not exceed $0.1 \%$.

The foam-forming capability of dry samples was determined by the relative increase in their solution volumes after shaking. For this purpose, a chemical glass was added weighed $25 \mathrm{~g}$ of dry product, and $225 \mathrm{~g}$ of distilled water with the temperature of $20^{\circ} \mathrm{C}$. The samples of $250 \mathrm{cu} \mathrm{cm}$ were shaken for $5 \mathrm{~min}$ at the frequency of shaker rotation of $800 \mathrm{rpm}$. After shaking the volume of liquid fraction and the volume of obtained foam were measured by a measuring glass cylinder. The foam-forming capability $(C, \%)$ was determined by the formula:

$$
C=\frac{V_{f} \cdot 100}{V_{m}}
$$

where, $V_{f}$ - volume of foam after shaking, cc; $V_{m}-$ the initial volume of the mixture prior to shaking, cc; 100 - coefficient of transferring into percentage.

The arithmetic mean value of the results of two parallel measurements was accepted as the final result after rounding down to the first decimal figure.

The moisture-retaining capability of dry products was determined by the increase in the mass of wet precipitate after centrifugation. A previously weighed centrifugal tube was introduced a weighed quantity in the amount of $1 \mathrm{~g}$ and $3 \mathrm{cc}$ of distilled water. The mixture was mixed for $1 \mathrm{~min}$. Then the tube was centrifuged at $8,000 \mathrm{rpm}$ for $15 \mathrm{~min}$. The liquid, which was above the precipitate, was poured out, the tube was turned over the filtration paper and left undisturbed for $10 \mathrm{~min}$ (to remove the remaining water) and weighed. The moisture-retaining capability $(M R C, \%)$ was calculated by the formula:

$$
M R C=\frac{C-B}{B-A} \cdot 100,
$$

where, $A$ - mass of an empty centrifugal tube, g; $B-$ mass of centrifugal tube with the weighed quantity of dry matter, $\mathrm{g}$; $\mathrm{C}$ - mass of centrifugal tube with precipitation after centrifugation, $g$.
The arithmetic mean value of the results of two parallel measurements was accepted as the final result after rounding down to the first decimal figure.

The fat-retaining capability of the investigated products was estimated using the emulsion solutions with refined oil. A previously weighed centrifugal tube was introduced a weighed quantity of dry product in the amount of $1 \mathrm{~g}$ and $3 \mathrm{cc}$ of refined oil. The mixture in the tube was mixed for $1 \mathrm{~min}$. Then the tube was centrifuged at $8,000 \mathrm{rpm}$ for $15 \mathrm{~min}$. The liquid, which was above the precipitate, was poured out, the tube was turned over the filtration paper and left undisturbed for $10 \mathrm{~min}$ (to remove the remaining refined oil) and weighed.

The fat-retaining capability $(F R C, \%)$ was calculated by the formula:

$$
F R C=\frac{C-B}{B-A} \cdot 100,
$$

where, $A$ - mass of an empty centrifugal tube, g; $B-$ mass of centrifugal tube with the weighed quantity of dry matter, g; $C$ - mass of centrifugal tube with precipitation after centrifugation, $g$.

The emulsifying capability of the investigated products was estimated using the emulsion solutions with refined oil. The chemical glass with the volume of 500 cc was introduced $7 \mathrm{~g}$ of dry product and $100 \mathrm{cc}$ of distilled water. The mixture was mixed using the mixer at 4,000 rpm for 5 min with subsequent addition of $100 \mathrm{cc}$ of refined oil and the mixing was continued at $8,000 \mathrm{rpm}$ for $5 \mathrm{~min}$. The emulsion was poured in equal parts into 4 calibrated centrifugal tubes with the volume of $10 \mathrm{cc}$ and centrifuged at 2,000 rpm for $5 \mathrm{~min}$. The emulsifying capability $(E C, \%)$ was calculated by the formula:

$$
E C=\frac{V}{V_{1}} \cdot 100,
$$

where, $V$ - volume of the liquid above the precipitate, cc; $V_{1}$ - total volume of centrifugal tube $(10 \mathrm{cc}) ; 100-$ coefficient of transferring into percentage.

The arithmetic mean value of the results of two parallel measurements was accepted as the final result after rounding down to the first decimal figure.

The mathematical processing of the results was conducted by methods of statistical analysis and standard algorithms of Microsoft Excel programs. The experiments were conducted in three repeats. The results were deemed to be reliable at $\mathrm{P}<0.05$. 


\section{ROMANCHUK et al.}

\section{RESULTS AND DISCUSSION}

Our previous studies established that during electrodialysis the mass share of ash in the initial whey decreased in the range from $0.56-0.71 \%$ to $0.02-0.08 \%$ after electrodialysis, depending on the kind of whey and the initial content of ash therein. The maximal decrease in the content of mineral salts in cheese milk whey was achieved using nanofiltration at the level of $40 \%$ [9, 10]. Regardless of different levels of demineralization, there was the most considerable decrease noted in the content of monovalent ions which led to improving organoleptic properties of dry whey [10]. This whey may be considered to be full value raw material during the production of other food products - cooked sausages, yogurts, ice-cream, cheese paste, cheeses, etc.

Taking the abovementioned into consideration, there was a study of the impact of combined application of membrane methods of processing whey on the composition and technological properties of the end products. Being the most common by-products of milk processing, formed during the production of cheese and sourmilk cheese, cheese and acid milk whey are usually processed by drying. Thus, the most attractive and economically grounded method is a possibility of improving the consumer properties of such dry products due to a high content of complete whey proteins therein.

The organoleptic and physical-chemical indices of liquid and dry products of processing cheese and acid whey were determined. It is noteworthy that in addition to dry kinds of whey, liquid demineralized whey with the mass share of dry substances of $\approx 20 \%$ is of some interest for practical application, for instance, for the production of sour-milk beverages. As noted above, the decrease in the content of ash in whey improves its taste properties considerably. The data, presented in
Table 1, demonstrate that after electrodialysis the indices of the mass share of ash (1) decreased in cheese and acid whey by 21.2 and $62.7 \%$ and after the treatment using both methods - by 9.6 and $14.7 \%$ respectively, compared to the initial content in the initial whey. The same tendency was remarked regarding the acidity indices as well: the values decreased for cheese and acid whey (after electrodialysis) 1.8 times and 4.2 times and 1.2 times and 2.7 times respectively, after the combination of treatment methods. Therefore, the decrease in the content of salts and lactic acid leads to improving organoleptic and physical-chemical indices of the end products.

It was established that during the treatment of whey with nanofiltration or during complex treatment with nanofiltration and further electrodialysis, the content of dry substances in liquid concentrate increased to $19 \ldots$ $20 \%$. This intermediate product of whey processing is full value raw material and may be used for normalization of milk mixtures while producing other milk products, sour milk beverages, etc.

It is obvious that the application of any method of processing whey or their combination allows improving the properties of the initial raw material considerably due to decreasing the content of ash (Table 2). For instance, after consecutive treatment using the methods of nanofiltration and electrodialysis, the indices of ash in dry whey (NF/ED) decreased 2.8 times in case of using cheese whey as the initial raw material and 3 times in case of acid whey. The demineralization level during electrodialysis may reach $86.5 \%$ for cheese whey and $95.8 \%$ for acid whey, and during the treatment using the combination of methods - up to $90 \%$ and $75 \%$.

To estimate the possibility of using dry demineralized whey (NF/ED), there was a determination of its function-

Table 1. The physical-chemical indices of liquid products of processing cheese and acid whey after different methods of treatment

\begin{tabular}{|c|c|c|c|c|c|c|c|c|}
\hline \multirow[t]{2}{*}{ Index } & \multicolumn{2}{|c|}{ Whey initial } & \multicolumn{2}{|c|}{$\begin{array}{l}\text { Liquid concentrate } \\
\text { after nanofiltration } \\
\text { (NF) }\end{array}$} & \multicolumn{2}{|c|}{$\begin{array}{l}\text { Dilute after } \\
\text { electrodialysis } \\
\text { (ED) }\end{array}$} & \multicolumn{2}{|c|}{$\begin{array}{l}\text { Liquid concentrate } \\
\text { combined method } \\
\text { of treatment }(\mathrm{NF} / \mathrm{ED})\end{array}$} \\
\hline & cheese & acid & cheese & acid & cheese & acid & cheese & acid \\
\hline Mass share of dry substances, $\%$ & 6.67 & 5.77 & 19.43 & 15.56 & 6.04 & 5.48 & 20.03 & 17.5 \\
\hline Mass share of ash, $\%$ & 0.52 & 0.75 & 1.0 & 1.1 & 0.41 & 0.28 & 0.47 & 0.64 \\
\hline Mass share of lactose, $\%$ & 4.50 & 4.02 & 15.20 & 10.43 & 4.90 & 5.0 & 6.71 & 5.92 \\
\hline Mass share of fat, $\%$ & $<0.1$ & $<0.1$ & 0.1 & 0.1 & $<0.1$ & $<0.1$ & 0.1 & 0.1 \\
\hline Titrated acidity, $0 \mathrm{~T}$ & 14.5 & 75.6 & 10.0 & 120 & 8.0 & 18 & 12.0 & 28 \\
\hline
\end{tabular}




\section{PHYSICAL-CHEMICAL COMPOSITION AND TECHNOLOGICAL PROPERTIES OF DEMINERALIZED MILK}

al-technological indices - foam-forming (2), moistureretaining (3), fat-retaining (4) and emulsifying (5) properties (Table 3). These properties characterize the ability of whey proteins to participate in surface phenomena and are most widely used while obtaining products on the basis of foam-like and emulsion systems. It is evident that such differences are possible due to the increase in protein content in dry demineralized whey.

The presented data demonstrate that the highest indices of moisture-retaining and fat-retaining capability were found for cheese whey, obtained by the combination of treatment methods, namely, $32.5 \%$ and $120 \%$ respectively. It is quite evident that it is due to the increased content of protein and the ability of whey proteins to bind water, emulsify and retain fats, dry cheese demineralized whey has better technological properties. A similar regularity was noted for foam-retaining capability as well.

Summarizing the abovementioned, one may assume that dry demineralized whey may be used as full value

Table 2. The characteristics of dry milk whey after treatment with different membrane methods

\begin{tabular}{|c|c|c|c|c|c|c|c|}
\hline \multirow{3}{*}{$\begin{array}{l}\text { Name } \\
\text { of indices }\end{array}$} & \multicolumn{2}{|c|}{$\begin{array}{l}\text { Dry whey (traditional } \\
\text { technology) }\end{array}$} & \multicolumn{5}{|c|}{ Dry demineralized whey } \\
\hline & \multirow[b]{2}{*}{$\begin{array}{l}\text { whey } \\
\text { cheese }\end{array}$} & \multirow[b]{2}{*}{$\begin{array}{l}\text { acid } \\
\text { whey }\end{array}$} & cheese & cheese & acid & cheese & acid \\
\hline & & & $\begin{array}{c}\text { after } \\
\text { nanofiltra- } \\
\text { tion (NF) }\end{array}$ & \multicolumn{2}{|c|}{$\begin{array}{l}\text { after electrodialysis } \\
\text { (ED) }\end{array}$} & \multicolumn{2}{|c|}{$\begin{array}{l}\text { combination of } \\
\text { treatment methods } \\
\quad(\mathrm{NF} / \mathrm{ED})\end{array}$} \\
\hline Mass content of dry substances, $\%$ & 97.00 & 95.19 & 97.87 & 95.06 & 94.52 & 97.00 & 94.80 \\
\hline Mass content of ash, $\%$ & 7.27 & 8.29 & 5.10 & 1.55 & 2.82 & 2.63 & 2.72 \\
\hline Mass content of lactose, $\%$ & 74.5 & 73.03 & 76.20 & 82.60 & 79.93 & 65.92 & 63.73 \\
\hline Mass content of fat, $\%$ & 1.50 & 1.6 & 0.5 & 0.5 & 1.0 & 1.0 & 1.0 \\
\hline Mass share of protein, $\%$ & 12.57 & 11.10 & 15.86 & 8.98 & 9.77 & 27.02 & 26.10 \\
\hline Titrated acidity, 0T & 14.0 & 75.0 & 9.5 & 8.0 & 25 & 12.0 & 18.0 \\
\hline $\begin{array}{l}\text { Index of solubility cc of wet } \\
\text { precipitate }\end{array}$ & 0.3 & 0.5 & 0.45 & 0.1 & 0.2 & $\begin{array}{l}\text { complete } \\
\text { solubility }\end{array}$ & 0.1 \\
\hline Level of demineralization, $\%$ & - & - & 43.35 & 86.5 & 95.8 & 90.0 & 75.0 \\
\hline \multicolumn{8}{|c|}{ Organoleptic indices } \\
\hline Consistence & \multicolumn{7}{|c|}{ Fine powder } \\
\hline Taste and smell & $\begin{array}{l}\text { Sweetish- } \\
\text { salty taste }\end{array}$ & $\begin{array}{c}\text { Sour- } \\
\text { salty taste }\end{array}$ & $\begin{array}{l}\text { Sweetish } \\
\text { taste }\end{array}$ & $\begin{array}{l}\text { Neutral } \\
\text { taste with } \\
\text { sweetish } \\
\text { flavor }\end{array}$ & $\begin{array}{l}\text { Neutral } \\
\text { taste with } \\
\text { slight sour } \\
\text { flavor }\end{array}$ & $\begin{array}{l}\text { Sweet } \\
\text { milk taste }\end{array}$ & $\begin{array}{l}\text { Milk taste } \\
\text { with slight } \\
\text { sour flavor }\end{array}$ \\
\hline Color & \multicolumn{7}{|c|}{ Light yellow color } \\
\hline
\end{tabular}

Table 3. The functional-technological properties of dry whey

\begin{tabular}{l|c|c|c|c}
\hline \multicolumn{1}{c|}{ Name of product } & $\begin{array}{c}\text { Foam-forming } \\
\text { ability, } \%\end{array}$ & $\begin{array}{c}\text { Moisture-retaining } \\
\text { ability, \% }\end{array}$ & $\begin{array}{c}\text { Fat-retaining } \\
\text { ability, \% }\end{array}$ & $\begin{array}{c}\text { Emulsifying } \\
\text { ability, } \%\end{array}$ \\
\hline Dry cheese whey (control) & $5.8 \pm 0.6$ & $12.2 \pm 0.1$ & $83.0 \pm 0.6$ & $27.0 \pm 0.4$ \\
Dry acid whey (control) & $4.3 \pm 0.2$ & $14.6 \pm 0.1$ & $79.0 \pm 0.2$ & $29.0 \pm 0.1$ \\
Dry cheese whey (NF/ED), demineralization level 90\% & $15.6 \pm 0.2$ & $32.5 \pm 0.01$ & $120.0 \pm 0.2$ & $33.0 \pm 0.2$ \\
Dry acid whey (NF/ED), demineralization level 75\% & $11.9 \pm 0.1$ & $27.4 \pm 0.02$ & $107.3 \pm 0.1$ & $31.8 \pm 0.1$ \\
\hline
\end{tabular}




\section{ROMANCHUK et al.}

replacement of dried skimmed milk and dry whey in the formulations of other food products with the purpose of improving their consumer and functional-technological properties.

\section{RESULTS}

It was established that there was high efficiency of applying membrane methods for processing of secondary resources of milk raw materials in current conditions of raw materials source, which are presented by milk whey, formed during cheese production. It was determined that processing of different kinds of whey using the combination of nanofiltration and electrodialysis methods led to a considerable decrease in the content of ash compared to the initial whey. The level of demineralization of cheese whey may amount to 90 $\%$, that of acid whey $-75 \%$. In addition to dry kinds of whey, liquid demineralized whey is of some interest for practical application, which may be used during the production of sour-milk and milk-containing drinks due to a high content of dry substances. It was found that the increase in protein content in dry demineralized whey, obtained using the complex of membrane methods of processing, led to a considerable increase in its foam-forming, moisture-retaining, fat-retaining and emulsifying abilities compared to milk whey, obtained by a traditional technology.

\section{CONCLUSIONS}

It was established that dry demineralized whey, obtained by a combination of nanofiltration and electrodialysis methods, had better organoleptic and physical-chemical indices compared to dry whey. The investigated industrial samples are remarkable for improved functional and technological properties which allows using them in the formulations of other food products.

\section{Фізико-хімічний склад та технологічні властивості сироватки молочної демінералізованої, отриманої мембранними методами}

\section{I. О. Романчук, А. В. Мінорова, Н. Л. Крушельницька}

Інститут продовольчих ресурсів НААН

Вул. Є. Сверстюка, 4а, Київ, Україна, 02002

e-mail: dairy@ipr.net.ua, MinorovaAnt@gmail.com, enn.makarova@gmail.com

Мета. Провести дослідження складу та властивостей зразків підсирної та кислої молочних сироваток, отриманих в промислових умовах із застосуванням комбінації методів нанофільтрації та електродіалізу. Методи. Визначення фізико-хімічних показників за стандартними методами, функціонально-технологічні властивості сироватки демінералізованої за загальноприйнятими методиками. Результати. Відмічено високу ефективність застосування мембранних методів для переробки вторинних ресурсів в існуючих умовах сировинної бази, якими на сьогоднішній день $є$ різні види сироватки молочної, що утворюються під час виробництва сирів. Встановлено, що обробка різних видів сироватки із використанням комбінації методів нанофільтрації та електродіалізу призводить до значного зменшення вмісту золи у порівнянні з вихідною сировиною. Рівень демінералізації підсирної сироватки може досягати 90 \%, кислої сироваток - 75 \%. Крім сухих видів сироватки певну зацікавленість для практичного застосування має рідка демінералізована сироватка, яка завдяки високому вмісту сухих речовин може використовуватися під час виробництва кисломолочних та молоковмісних напоїв. Встановлено, що зі збільшенням вмісту білка у сухій демінералізованій сироватці, отриманій за допомогою комплексу мембранних методів обробки, іiі піноутворююча, вологоутримуюча, жироутримуюча та емульгуюча здатність у порівнянні із сироваткою молочною, отриманою за традиційною технологією, істотно зростає. Висновки. Встановлено, що суха демінералізована сироватка, одержана із використанням комбінації методів нанофільтрації та електродіалізу, має кращі органолептичні та фізико-хімічні показники у порівнянні з сироваткою сухою. Досліджені промислові зразки характеризуються покращеними функціонально-технологічними властивостями, що дозволяє використовувати їх під час виробництва інших харчових продуктів.

Ключові слова: нанофільтрація, електродіаліз, комбіновані мембранні методи, фізико-хімічні показники, рівень демінералізації, сироватка демінералізована суха, функціонально-технологічні властивості.

\section{Физико-химический состав и технологические свойства сыворотки молочной деминерализованной, полученной мембранными методами}

\section{И. О. Романчук, А. В. Минорова,} Н. Л. Крушельницькая

\author{
Институт продовольственных ресурсов НААН \\ Ул. Е.Сверстюка, 4а, Киев, Украина, 02002. \\ e-mail: dairy@ipr.net.ua, MinorovaAnt@gmail.com, \\ enn.makarova@gmail.com
}

Цель. Провести исследования состава и свойств образцов подсырной и кислой молочных сывороток, полученных в промышленных условиях с применением комбинации методов нанофильтрации и электродиализа. Методы. Определение физико-химических показателей за стандартными методами, функциональнотехнологические свойства сыворотки деминерализованной по общепринятым методикам. Результаты. Отме- 


\section{PHYSICAL-CHEMICAL COMPOSITION AND TECHNOLOGICAL PROPERTIES OF DEMINERALIZED MILK}

чено высокую эффективность применения мембранных методов для переработки вторичных ресурсов молочного сырья в существующих условиях сырьевой базы, которыми на сегодняшний день является сыворотка молочная, которая получается при производстве сыров. Установлено, что обработка различных видов сыворотки с использованием комбинации методов нанофильтрации и электродиализа приводит к значительному уменьшению содержания золы по сравнению с исходным сырьем. Уровень деминерализации подсырной сыворотки может достигать $90 \%$, кислой сыворотки - $75 \%$. Кроме сухих видов сыворотки определенную заинтересованность для практического применения имеет жидкая деминерализованная сыворотка, которая благодаря высокому содержанию сухих веществ может использоваться при производстве кисломолочних и молокосодержащих напитков. Установлено, что с увеличением содержания белка в сухой деминерализованной сыворотке, полученной с помощью комплекса мембранных методов обработки, ее пенообразующая, влагоудерживающая, жироудерживающая и эмульгирующая способность по сравнению с сывороткой молочной, полученной по традиционной технологии, существенно возрастает. Выводы. Установлено, что сухая деминерализованная сыворотка, полученная с использованием комбинации методов нанофильтрации и электродиализа, имеет лучшие органолептические и физикохимические показатели по сравнению с сывороткой сухой. Исследованные промышленные образцы характеризуются улучшенными функционально-технологическими свойствами, что позволяет использовать их при производстве пищевых продуктов.

Ключевые слова: нанофильтрация, электродиализ, комбинированные мембранные методы, физико-химические показатели, уровень деминерализации, сыворотка деминерализованная сухая, функционально-технологические свойства.

\section{REFERENCES}

1. Zolotareva MS, Volodyn DN, Topalov VK, Yevdokymov $I A$, Chaplin $B V$. On processing milk whey and introduction of the best available technologies. Pererabotka moloka. 2016;7:17-9.

2. Yevdokimov IA, Volodin IA, Chaplin BV, Mikhneva
$V A$. Membrane technologies in dairy production. Molochnaya promyshlennost. 2013;9:25-6.

3. Zolotareva MS, Volodin DN, Topalov VK, Chaplin BV. Membrane equipment for processing of various kinds of milk resources. Molochnaya promyshlennost. 2016;9: 60-1.

4. Hinkova A, Zidova P, Pour V, Bubnik Z. Potential of membrane separation processes in cheese whey fractionation and separation. Procedia Engineering. 2012; 42:1554-65.

5. Varivoda AA. Membrane-processed milk whey in the technology of cheese spreads. Mezhdunarodny nauchnoissledovatelsky zhurnal. 2014;2-1(21):80-4.

6. Shohalova VN, Kuzin AA, Dykalo Nya, Shohalov VA. Content of NF-concentrates of caseic whey. Molochnaya promyshlennost. 2014;12:55-6.

7. Simova $H$, Kysela $V$, Cernin A. Demineralization of natural sweet by electrodialysis at pilot-plant scale. Desalination and Water Treatment. 2010;14:170-73.

8. Yevdokimov IA, Dykalo NYa, Volodin DN. Demineralization of salty cheese whey by electrodialysis. Molochnaya promyshlennost. 2006;6:28-9.

9. Minorova AV, Romanchuk IO, Nedorizaniuk OP, Krushelnytska NL. Milk whey processing using electrodialysis treatment. Visnyk ahrarnoi nauky. 2010;3:58-60.

10. Hondar OP, Romanchuk IO. Change in the mineral composition of dry milk whey at different methods of treatment. Collection of scientific works of Vinnytsia National Agrarian University. 2015;1(89).1:94-9.

11. Greiter M, Novalin S, Wendland M. Electrodialysis versus ion exchange: comparison of the cumulative energy demand by means of two applications. J. of Membr. 2004; 233:11-9.

12. Chao Yu-M, Liang TM. A feasibility study of industrial wastewater recovery using electrodialysis reversal. Desalination. 2008;221:433-9.

13. Greiter, Novalin S, Wendland M. Desalination of whey by electrodialysis and ion exchange resins: analysis of both processes with regard to sustainability by calculating their cumulative energy demand. J. of Membr. 2002; 210:91-102.

14.Zolotareva MS, Volodin DN, Bessonov AS, Topalov $V K$. Electrodialysis - the most efficient process of demineralizing milk whey. Molochnaya promyshlennost. 2014;3:37. 